\title{
Inclusive design in the implementation of projects for schools modernization in Portugal - case studies
}

\author{
Lígia Lopes ${ }^{\mathrm{a},{ }^{*}}$, Carlos Aguiar ${ }^{\mathrm{b}}$, Fernando Moreira da Silva $^{\mathrm{c}}$ \\ ${ }^{\mathrm{a}}$ CIAUD, Research Centre in Architecture, Urban Planning and Design, Faculty of Architecture, Technical \\ University of Lisbon. E-mail: ligia.mplopes@gmail.com \\ ${ }^{b}$ FEUP, Faculty of Engineering, University of Porto.E-mail: aguiar@fe.up.pt \\ ${ }^{\mathrm{C}}$ CIAUD - Research Centre in Architecture, Urban Planning and Design, Faculty of Architecture, Technical \\ University of Lisbon.E-mail:fms.fautl@gmail.com
}

\begin{abstract}
The Project for Schools Modernization taking place in Portugal, with an estimated total investment of 2450 million for the intervention in the first 205 schools, provide the reclassification of 332 secondary schools by 2015 . One of the questions we can pose is if the authorities and the teams of architects selected to design these schools considered fundamental for the correctness of architectural barriers within the school and its accessibility the implementation of standards and principles of inclusion of children/teenagers with special needs within their school environment. As most of the projects are already being implemented, the main aim of this paper is to present the outcomes of a comparative analysis and synthesis of six schools located in the northern part of the country. This analysis occurs from the of Participatory Design perspective which appeals to the experience of the disable children to look (or evaluate) the negative and positive factors in terms of physical space, interpreted by inclusive design rules and orientations. Therefore, the evaluation of schools modernization project, and its discussion, is central for the understanding how these children are addressed in projects which are directed at them.
\end{abstract}

Keywords: Ergonomics, Inclusive Design, Schools, Children with cerebral palsy.

\section{Introduction}

The first modern secondary schools, those which were specifically designed to serve this function, go back to 1906 with the opening of the Alexandre Herculano and the Pedro Nunes High Schools in Porto and the Camões and the Passos Manuel, in Lisbon.

After the 25 April Revolution, in 1974, and mainly in the 80's, the largest percentage of existing secondary schools in the Portugal were built. Most of these buildings are in degradation or obsolescence in terms of functional competencies required by the current education plan in Portugal, these buildings are part of an architectural and historical heritage both highly valued by the class of architects or by the population in general.

The rehabilitation of these buildings by adapting them to current requirements is by itself a challenge and somehow restrictive and adds responsibility to the design team when rehabilitating the buildings designed by authors such as Marques da Silva, Ventura Terra or Carlos Ramos, as underlined by Alexandre Alves Costa (2008) and, therefore, also represents a large public investment and also of the involved community.

As designers we understand the importance and the heritage value of these buildings even if we pursue the implementation of values and attributes that allow a more inclusive approach to the spaces.

With the present analysis, it was possible to verify that the accessibility standards required and applied in Portugal, do not constitute a large improvement of physical and ergonomic conditions of spaces, still existing gaps in the regulation which allow circumventing the legislation in favor of aesthetics.

In 2015 it is expected that 332 high schools in Portugal have suffered architectural requalification. 
The conclusions present in this project reflect the deep analysis of "Parque Escolar" projects within the Porto District, some of them already completed and others that haven't been changed yet, as the Art High School Soares dos Reis, Secondary School of Valadares, Rodrigues de Freitas, Padrão da Légua, among others.

\section{Guidelines}

Children with cerebral palsy are mostly integrated into the regular public education, although depending on the level of cerebral palsy (with more or less mobility limitations), these children are extremely sociable, intelligent and engaged in the recovery process and in learning.

Their monitorization, therapies and physical therapies are implemented in centers which provide support to children and their families in recovering some movement and speech and in the restructuring of the family space.

In advance, it is known that we can be using as study group a minority of students. But when offering an integrated education system, physical and ergonomic conditions should not be provided in the classroom outside space? It is for these children that we drove this study, although the raised concerns are also useful for teaching and non-teaching staff that have the same or other limitations.

In the visited and evaluated schools for this study, it is possible to find gaps as basic as support for runners with no rest, no ramps where children can move in the aisles side by side with friends, forcing them to alternative paths leading to elevators in areas of lower circulation. Figures 1 and 2 show that not always a lack of space can justify the gaps in accessibility.

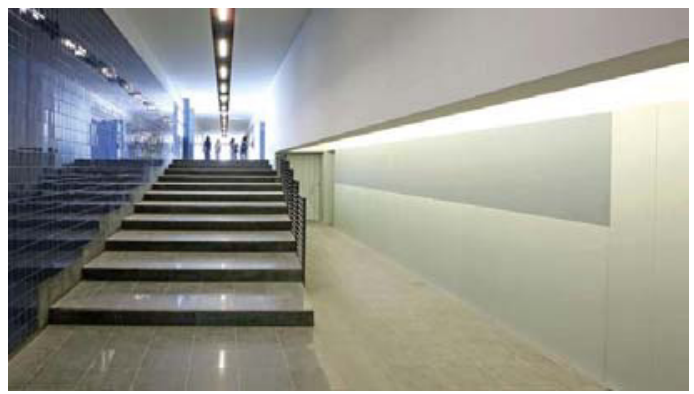

Figure 1 - building interior, Artistic High School Soares dos Reis. Project: Carlos Prata, architect.

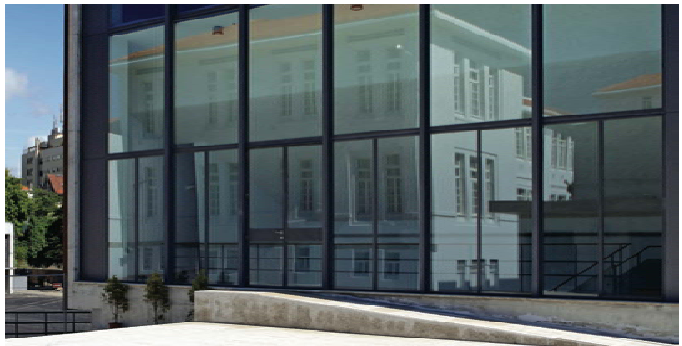

Figure 2 - Building access ramp. High School Rodrigues de Freitas. Project: Manuel Fernandes de Sá, architect.

Every day we collude with gaps like this presented project. The spacing of steps does not help motor coordination due to the high distance between them. In physical accessibility issues we can find several examples in the schools evaluated in this study that meet Portuguese Accessibility Standards creating alternative routes for the disabled people not removing the stigma that often these objects symbolize.
Are we designing for Exclusion?

"The concept of design exclusion is particularly powerfull bexause identifying why and how endusers cannot use a product enables us to counter such exclusion. (...) Designers instinctively focus on providing the necessary utility (functionality) for someone with physical and skill capabilities similar to their own (Cooper, 1999), unless specifically instructed to do otherwise. They are either unaware of the needs of users with different capabilities, or do 
not know how to accommodate their needs into the design cycle." [5], p.89.

\section{Discussions and questions}

When establishment of a parallelism between Past and Present, between Heritage and rehabilitation, between designers and end users, some questions still remain. For some of them it possible to find proposals which may represent an improvement in the quality of spaces. We try to project together, participatory design, allowing users and people who accompany these children every day, to interfere in the design process. We ask these "new designers" to help us to solve physical, linguistic and communicational barriers.

Here are some concerns as designers and evaluators of the process:

1. Are we still on time to propose studios and designers a new methodology of approach to the group of individuals/users in question?

2. Can children with a disability and their families integrate the design team? Are they sufficiently prepared to think critically and help to solve problems that, although similar are not theirs?

3. With the recon of physical and ergonomic problems presented by children with cerebral palsy, or others who have some other type of physical disability, can we also find coincident problems of other groups with special needs? Which?

4. Can we propose interventions in requalification involving a low-cost, justifying the improvement by ergonomic issues?

\section{Conclusions}

A reflection on values and social responsibility of the project teams, forces us as designers to establish a dialogue between planners and Multidisciplinary groups looking for solutions that in any way do not change the intent of the project but may respond to the needs of a group of people as wide as possible.

Most of the projects for the "Parque Escolar" already finished are "cold", developed at the image of a traditional Portuguese architecture school but responds to the comfort needs of who is disabled.
These needs can fit the physical, linguistic or communicational difficulties.

Collection and analysis of the evaluations should be wider as possible. To the experience as planners we add with the experts testimony in various quadrants as Psychology, Occupational Therapists, Physiotherapists to the Families and especially involve children in the process of participatory design and co-design.

The research team continues from this case study to a new project: to design a School Kit for Inclusiveness which may be incorporated into the projects already requalified and others that are underway, creating a language that can be used in the "Parque Escolar" and as well as in units directed to children, allowing the sharing of "common space" for children with cerebral palsy.

\section{References}

[1] August, J et al, 2004, Playground at Marcus Garvey Park for children with physical disabilities, Design Team 1, Final written report, Columbia.

[2] C. Jones, L. McIver, L. Gibson and P. Gregor, Experiences obtained from designing with children. in small Users - big ideas, Conf. Proc. of Interaction Design and Children, ACM Press (2003), 69-74.

[3] G. Bonsiepe and T. Yamada, Desenho industrial para pessoas deficientes, Concelho Nacional de Desenvolvimento Científico e Tecnológico, Brasília (1982)

[4] J. Cassim, (ed), Innovate 6: why getting it right for people with disabilities means getting it right for all, Helen Hamlyn Centre, London (2004)

[5] J. Clarkson et al, Inclusive Design: Design for all Population, Springer Verlag (2003)

[6] J.F. Simões and R. Bispo, Design inclusivo, acessibilidade e usabilidade em produtos, serviços e ambientes, Centro Português de Design, $2^{\text {a }}$ Edição, Lisboa (2006)

[7] J.M. Porter, Beyond Jack and Jill - designing for individuals within populations. The Ergonomist, September 3 (2001)

[8] L. Gibson, P. Gregor and S. Milne, Case study: designing with difficult children. In proc. of Interaction design and Children, Shaker Publishing (2002), 42-52.

[9] M.F. Story, J.L. Muller and R.L. Mace, The universal design file - designing for people of all ages and abilities, The Center for Universal Design, NC State University - Raleight (1998)

[10] Manual de Projecto para a Acessibilidade nas Escolas, Parque Escolar E.P.E, LPDM-CRS, CPD, Lisboa (2008)

[11] Planning and Designing for Students with Disabilities, National Clearinghouse for educational facilities, New York (2004)

[12] R. Imrie and H. Peter, Inclusive Design: design and developing accessible environments, 1st Ed, London (2001)

[13] S. Keates and P.J. Clarkson, Defining Design Exclusion, Universal Access and assistive technology, Springer Verlag (2002)

[14] SENDA (Special Educational Needs and Disability Act) (2001) www.uk-legislation.hmso.gov.uk/acts.htm 
[15] SNRIPD, Acessibilidade e mobilidade para todos -

Apontamentos para uma melhor intergração do DL 163/2006 de 8 de Agosto, Ed. Secretariado Nacional para Reabilitação e Integração das Pessoas com Deficiência. 